Зварич I. T., д.політ.н., професор

Зварич О. І., д.е.н., доцент

Прикарпатський наџіональний університет імені Василя Стефаника м. Івано-Франківськ, Україна

DOI: https://doi.org/10.30525/978-9934-26-064-3-9

\title{
МЕНЕДЖМЕНТ МІСЦЕВИХ БЮДЖЕТІВ У СИСТЕМІ БЮДЖЕТНОГО ПРОЦЕСУ В УКРАЇНІ
}

У загальному значенні бюджет (від англ. budget - сумка) це розподіл грошових доходів і витрат держави, регіону, підприємства та організації на певний період або ж сукупність різних доходів і видатків фізичної особи чи сім'ї. У відповідності із Бюджетним кодексом України [1] бюджет є планом формування та використання фінансових ресурсів для забезпечення завдань і функцій, що здійснюються органами державної влади, органами влади Автономної Республіки Крим та органами місцевого самоврядування у бюджетному періоді. Бюджетна система України - це упорядкована сукупність державного i місцевих бюджетів, яка побудована 3 врахуванням економічних стосунків, державного та адміністративно-територіальних устроїв і належно врегульована відповідними нормами права. Відтак, системне дослідження їхнього впливу на соціально-економічний та культурний розвиток вітчизняних регіонів має як значне теоретичне, так і доволі істотне практичне значення.

Конституція України [2]; Бюджетний кодекс України [1]; Закон про Державний бюджет України [3] та інші законодавчі акти, якими регулюються сучасні бюджетні правовідносини і які передбачаються Бюджетним кодексом України; нормативноправові акти Кабінету Міністрів України, що приймаються на підставі та на виконання Бюджетного кодексу та інших законів України; нормативно-правові акти центральних органів виконавчої влади, які ухвалюються на основі та на виконання Бюджетного кодексу та інших законів України, як і нормативно- 
правових актів Кабінету Міністрів України; рішення органів АРК, місцевих державних адміністрацій та органів місцевого самоврядування, що прийняті у відповідності із Бюджетним кодексом України та іншими законами України і нормативноправовими актами Кабінету Міністрів України та відповідних центральних органів державної виконавчої влади.

Бюджетна система України складається із Державного бюджету України та місцевих бюджетів (рис. 1), до яких належать бюджет АРК, обласні, районні бюджети, бюджети районів у містах і бюджети місцевого самоврядування. Бюджети місцевого самоврядування - бюджети територіальних громад, сіл, селищ, міст та їх об’єднань.

Вони $є$ самостійними i не включаються до Державного бюджету України та до інших (місцевих) бюджетів [4-8].

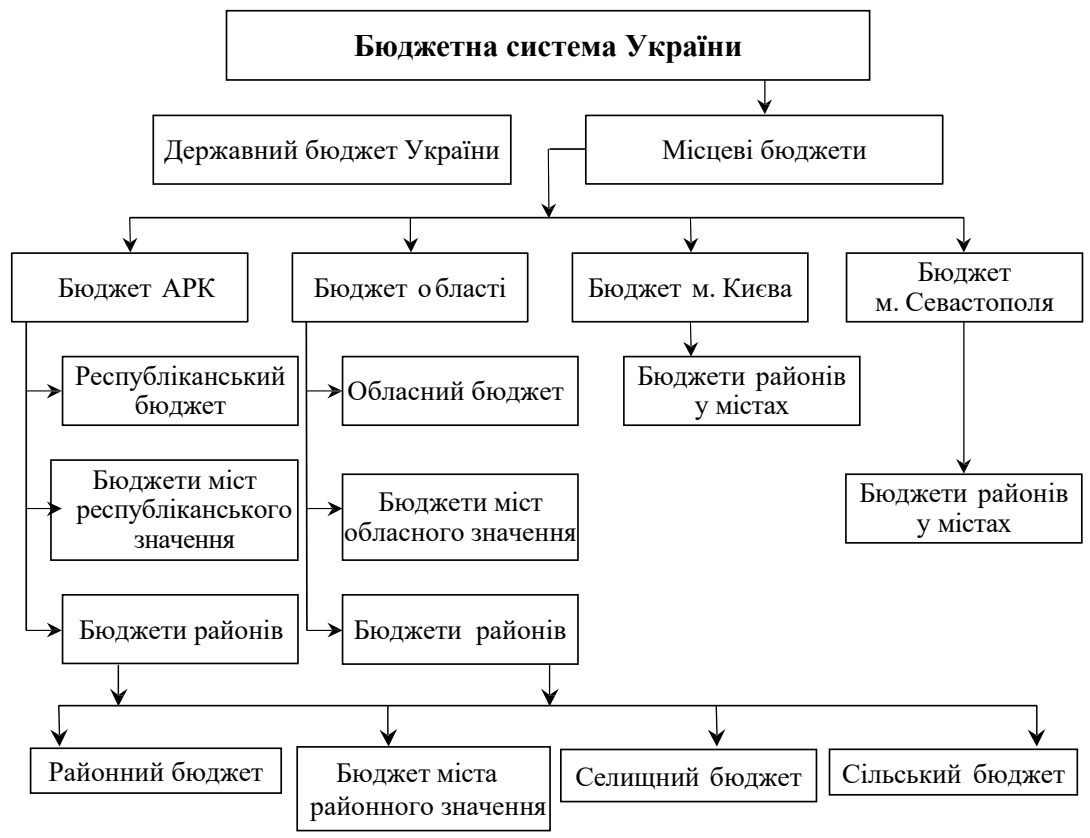

\section{Рис. 1. Структура бюджетної системи України}

Джерело: [1; 5-6] 
Місцевий бюджет у відповідності із Бюджетним кодексом містить надходження i видатки на здійснення повноважень органами влади АР Крим, місцевими державними адміністраціями та органами місцевого самоврядування. У відповідності 3 Конституцією України та статтею 9 «Фінансові ресурси органів місцевого самоврядування Європейської хартії про місцеве самоврядування [9] місцеві бюджети є фінансовою базою органів місцевого самоврядування та визначальним чинником соціальноекономічного регіонального розвитку. Їхня наявність закріплює належну економічну самостійність органів місцевого самоврядування, яка передбачається чинною Конституцією [2] та Законом України «Про місцеве самоврядування в Україні» [6], істотно активізує господарську діяльність і дає можливість належно розвивати інфраструктуру на підвідомчій території та розширювати економічний потенціал регіону, виявляти i використовувати усі резерви фінансових ресурсів. У результаті розширюються можливості місцевих органів влади у більш повному задоволенні потреб населення. Місцеві бюджети є i основним каналом доведення до населення результатів суспільного виробництва, що спрямовуються на належне суспільне споживання. Через них сформовані суспільні фонди споживання відповідно розподіляються у територіальному та соціальному аспектах. Разом із іншими ланками бюджетної системи України місцеві бюджети є і одним із визначальних інструментів належної реалізації у безпосередній практиці програм соціально-економічного та культурного розвитку як регіонів, так і державами.

Як відповідна економічна категорія місцеві бюджети відображають обумовлену адміністративним поділом та бюджетним устроєм країни сферу економічних відносин суспільства, пов'язаних із формуванням, розподілом і використанням централізованих коштів, які знаходяться у повному розпорядженні місцевих органів влади, призначених для соціально-економічного та культурного розвитку регіонів держави, займаючи одне із центральних місць у іiі економічному механізмі. Водночас їх роль і значення безпосередньо зумовлені відповідним типом 
економічної системи та обраними цілями i пріоритетами суспільного розвитку. Отже, основними домінантами складної та багатопланової ролі місцевих бюджетів $є$ те, що вони є: визначальним чинником економічного розвитку і фінансової стабільності та інструментом макроекономічного регулювання; засобом здійснення перерозподільчих процесів; фінансовою базою місцевого самоврядування; інструментом реалізації державної регіональної політики; безпосередніми планами формування і належного використання наявних фінансових ресурсів відповідних територіальних утворень; основним важелем здійснення фінансового вирівнювання; головним джерелом фінансових ресурсів із метою утримання та розвитку місцевого господарства і врегулюванням місцевих проблем; ключовим засобом реалізації різноманітних перспективних цілей національного розвитку та загальнодержавних програм і здійснення фінансування державних видатків; ефективним механізмом забезпечення конституційних гарантій та розв'язання соціальних проблем, як i подальшого підвищення добробуту громадян України.

Відтак, досліджуючи проблематику місцевих бюджетів, їх потрібно розглядати у двох таких аспектах: по-перше, як організаційну форму мобілізації частини фінансових ресурсів у розпорядження місцевих органів самоврядування; та, по-друге, як систему фінансових відносин, які складаються між місцевими $\mathrm{i}$ державним бюджетами та всередині їх сукупності. Водночас як організаційна форма мобілізації доходів і здійснення витрат органами місцевого самоврядування бюджети - це балансові розрахунки, що відповідають встановленим вимогам до складання балансів, тобто мають дохідну та видаткову частини, у їхню основу покладено принцип збалансованості тощо.

Одночасно як відповідна економічна категорія місцеві бюджети відображають обумовлену адміністративним поділом i бюджетним устроєм держави сферу економічних відносин у суспільстві, які пов'язані із формуванням, розподілом та використанням централізованих коштів, що знаходяться у 
повному розпорядженні відповідних місцевих органів влади, чим створюються належні умови для системного управління відповідними місцевими бюджетами як невід'ємної складової частини чинного бюджетного процесу в Україні.

\section{Література:}

1. Бюджетний кодекс України (зі змін. і доп.). Затверджений Законом України від 8 липня 2010 року № 2456-VI. URL: http://zakon1.rada.gov.ua (дата звернення: 27.02.2021).

2. Конституція України (зі змін. та доп.). Прийнята на п'ятій сесії Верховної Ради України 28 червня 1996 року. URL: http://zakon.rada.gov.ua (дата звернення: 27.02.2021).

3. Державний бюджет України на 2021 рік (зі змін. і доп.). Затверджений Законом України від 29 січня 2021 року № 1158-IX. URL: http://zakon.rada.gov.ua (дата звернення: 27.02.2021).

4. Єпіфанов А.О., Мінченко М.В., Додашев Б.А. Управління регіоном: навч. посібн. За заг. ред. д-ра екон. наук А.О. Єпіфанова. Суми : ДВНЗ «УАБС НБУ», 2008. $361 \mathrm{c.}$

5. Закон України від 21 травня 1997 року. № 280/97-ВР «Про місцеве самоврядування в Україні» (зі змін. та доп.). URL: http://zakon2.rada.gov.ua (дата звернення: 27.02.2021).

6. Зварич І.Т., Зварич О.І., Хома В.Б. Управління соціально-економічним розвитком регіону: навч.- метод. посібн. для студ. і магістр. усіх екном. спец. Івано-Франківськ : Вид-ць «ПП Супрун В.П.», 2019. 476 с. Рис. 24. Табл. 40. Бібліогр. 73 наймен.

7. Зварич О.В. Прогнозування податкових надходжень у системі формування доходів бюджету : автореф. дис. на здоб. наук. ступ. канд. екон. наук за спец. 08.00.08 «Гроші, фінанси і кредит». Київський нац. екон. ун-т. Київ, 2012. 19 с.

8. Малиняк Б. Трансформація місцевих бюджетів в ефективне джерело зростання суспільного добробуту. Вісник Тернопільського наи. економ. ун-ту. Вип. 2, 2015. С. 73-85. URL: http://nbun.gov.ua/UJRN/Vtneu201528 (дата звернення: 27.02.2021).

9. Європейська хартія місцевого самоврядування. URL: http://zakon.rada.gov.ua (дата звернення: 27.02.2021). 